\title{
Model-based assessment of local-scale fish larval connectivity in a network of marine protected areas (MPAs)
}

\author{
GOTZON BASTERRETXEA ${ }^{1}$, ANTONI JORDI ${ }^{1}$, IGNACIO A. CATALÁN ${ }^{1}$, ANA \\ SABATÉS ${ }^{2}$. \\ ${ }^{1}$ Instituto Mediterráneo de Estudios Avanzados, IMEDEA (UIB-CSIC), Miquel Marqués \\ 21, 07190 Esporles, Mallorca, Spain \\ ${ }^{2}$ Institut de Ciències del Mar (CSIC), Pg. Marítim de la Barceloneta, 37-49, 08003 \\ Barcelona, Spain.
}

Submitted to: Fisheries oceanography

Running head: Local-scale connectivity in a network of MPAs 


\section{ABSTRACT}

We assessed by numerical modeling the coastal fish larval dispersion along the southern coast of Mallorca (Balearic Islands, NW Mediterranean) with the objective of determining the factors that contribute to successful recruitment. We assumed that fish larvae dispersal is mainly regulated by physical transport. Currents are mainly wind driven in this area; therefore, changes in wind forcing have a first-order impact on larval transport. The synoptic wind patterns were systematically analyzed based on self-organizing map analysis. The wind fields were clustered using a neural network pattern recognition approach into two modes, producing opposite along-shelf flow. The seasonal changes between spring and summer in the dominance of either mode modulate the along-shelf circulation, producing flow shifts under some circumstances. This variability in the wind regime was consistent throughout the 10 years analyzed (2000-2009). Using the Princeton Ocean Model (POM) and a particle-tracking algorithm, we analyzed the effect of windforced currents in the connectivity among near-shore habitats. We show that, at the spatial scale considered, the coastal morphology and stochastic wind forcing favor local recruitment (mean of 30\% self-recruitment). Maximum transport distances of 20-30 km were typically associated with particles left to drift for 21 days. The implications for the performance of the four marine protected areas near SW Mallorca Island are discussed. Our results suggest that, although wind episodes determine the fate of short-time spawning events, on a seasonal basis, regular larval supply to coastal zones is ensured by wind stochasticity. 
Key words: dispersal, larvae, connectivity, coastal, marine protected area, Mediterranean

1

2

3

4

5

6

7

9

10

11

12

13

14

15

16

17

18

19

20

21

22

23

24

25

26

27

28

29

30

31

32

33

34

35

36

37

38

39

40

41

42

43

44

45

46

47

48

49

50

51

52

53

54

55

56

57

58

59

60 


\section{INTRODUCTION}

Many marine fishes have a planktonic larval phase that occurs in the water column away from the adult habitat. During this pelagic stage, the larvae are capable of broad dispersal, and their return to the adult populations is often variable, resulting in substantial fluctuations in the population size (e.g., Roberts, 1997; Pedersen et al., 2003; but see Leggett and Frank, 2008). The flow-induced pelagic dispersal patterns of fish eggs and larvae from their spawning grounds are crucial for determining the survival of reef and coastal fishes that require reaching a suitable settlement site at the end of a relatively short larval stage (weeks to months). Thus, the supply of larvae is the determinant of the stability of the open populations of fishes that depend upon the return and settlement of the planktonic larvae to balance the adult mortality losses (Cowen, 1985; Sinclair, 1988; Sponaugle and Cowen, 1996). Furthermore, knowledge of the patterns of larval dispersal between benthic habitat patches is critical to understanding the connectivity and persistence of marine metapopulations (Hastings and Botsford, 2006; Sale et al., 2006, Pineda et al., 2007).

The traditional view of the potentially high dispersal for marine propagules (e.g., Roughgarden et al., 1988; Siegel et al., 2003) has been tempered by the growing evidence of restricted dispersal, which would imply that local recruitment is more important than previously thought (Jones et al., 1999; Jones et al., 2005; Knutsen et al., 2007). The interaction of different biophysical mechanisms may fully or partially counter dispersion and enable the retention of larvae near their natal source. The relative importance of passive 
versus active larval behavior mechanisms in coastal recruitment is still unclear because, among other reasons, these relationships vary among species and larval developmental stages (Leis, 2007). Fish larvae are able to perform vertical diel migrations that significantly affect their final location (Leis, 2007; Vikebø et al., 2007). Furthermore, they may follow ambient cues at the horizontal scale to successfully reach nursery areas or survive (e.g., Bradbury and Snelgrove, 2001; Leis, 2010; Vermeij et al., 2010). The extent to which the larval behavior affects recruitment is still under discussion. In addition to the behavioral aspects, many of which are still unresolved for several fish species, different studies show that physical and biological processes that promote the retention and aggregation of larvae in the appropriate environmental conditions for their development and growth probably determine their survival and increase recruitment. These results suggest an important role of physics in the persistence and distribution of many fish populations (Kingsford and Suthers, 1994; Hinckley et al., 1996; Agostini and Bakun, 2002).

The inner shelf circulation is of particular importance in the dispersal processes of coastal fish species that exhibit a strong relationship to particular littoral habitats, such as seagrass beds, sandy seabeds or rocky shores, from which they rarely migrate. Among the physical processes determining recruitment success in the inner-shelf (i.e. where bathymetry is $<50 \mathrm{~m}$ ), wind-driven flow plays a major role in transporting eggs and larvae towards or away from coastal nursery grounds (Norcross and Shaw, 1984). This phenomenon is because most marine fish eggs are buoyant and therefore are affected by wind-induced surface layer transport. Variations in wind fields have been associated with the variability in the initial dispersal of larvae (Appeldoorn et al., 1994; Hinrischsen et al., 
2003), recruitment (Cury and Roy, 1989; Kingsford and Finn, 1997) and the abundance of adult stocks (Bailey 1981; Myers and Drinkwater 1988; Shenker et al.1993). This physical variability acts at different temporal scales. For example, although shifts in prevailing currents induce seasonal and interannual variability, episodic events and local scale oceanographic structures are related to intra-seasonal variability (Sponaugle and Cowen, 1996).

Understanding how fish populations are interconnected by larval dispersal is essential to the successful management of living marine resources, especially when considering spatial management measures, such as marine protected areas (MPAs) (Almany et al., 2009). For MPAs to be successful in protecting marine populations, an individual MPA must be self-sustaining or adequately connected to other MPAs via larval dispersal. Information on larval dispersal is critical in practical terms because the degree of connectivity among geographic areas sets the scale at which management strategies for exploited marine species need to be applied. Understanding larval dispersal mechanisms, rates, and distances can help to determine the optimal size and location of MPAs and adequately protect connectivity (Sala et al., 2002; Sale et al., 2005; Laurel and Bradbury, 2006). Studies of fish larvae connectivity have revealed a high range of variability, from high levels of self-recruitment within a specific area to a significant dispersal among areas, at scales of tens of km (Planes et al. 2009). Relevant levels of larval connectivity may be modified by the availability of recruitment habitat (Jones et al., 2007) and a suite of postrecruitment processes (Hamilton et al., 2008).

The inner shelf circulation around Mallorca is considered to be relatively uncoupled from regional oceanographic features because of the low tidal forcing in the Mediterranean; 
therefore, wind-induced processes are particularly important (Jordi et al., 2011). Seagrass meadows, which extend down to depths of $40 \mathrm{~m}$, have long been argued to be important nursery areas because their high productivity and structural complexity provide both enhanced foraging opportunities and refugia from predators for larvae and juvenile fishes; therefore, they are important for sustaining the biodiversity of fish assemblages (e.g., Howard et al., 1989). Despite the increasing concern for and economic valuation of littoral fish species associated with recreational and artisanal fisheries in temperate areas (Cooke and Cowx, 2004; Morales-Nin et al., 2005), little is known about the scale of their connectivity patterns and how MPAs can be efficiently used for conservation or fisherymanagement purposes (Morales-Nin et al., 2010). With some overlaps, species such as Coris julis, Symphodus ocellatus, Diplodus annularis, Sarpa salpa, Serranus scriba and Spondyliosoma cantharus typically inhabit the Posidonia oceanica seagrass beds, whereas species such as Symphodus roissali, Symphodus tinca or Diplodus sargus are associated with the rocky-algal reef habitats. Other conspicuous species, such as Gymnammodytes cicerellus, Lithognathus mormyrus, Gobius geniporus, Mullus barbatus or Uranoscopus scaber, are observed over sandy areas. The adults of some of the littoral species associated with seagrass beds have narrow home ranges of less than $1 \mathrm{~km}^{2}$ (March et al., 2010), which may imply that the adult populations are highly sensitive to local management actions, including the establishment of MPAs. This high preference for some habitats, and in some cases the scarcity of some of these habitat types, means that some species settle in practically the same sheltered sites year after year (Macpherson, 1998; Vigliola et al., 1998). Furthermore, these protected areas have been reported as important spawning areas for targeted fishery species (Crec'hriou et al., 2010). 
Because of the importance of the artisanal and recreational fishery to the economy of many islands of the Mediterranean Sea and the ongoing efforts towards stock management through the development of MPAs (Goñi et al., 2000; Gell and Roberts, 2003), the larval dispersal patterns of coastal fish species in temperate areas, where research is rather limited in comparison with coral reef zones, merit further attention. Evidence from hydrodynamic models and genetic data indicate that the scales of dispersal can vary widely at different locations in space and time (e.g., Cowen et al., 2003; Sotka et al., 2004). The purpose of this study was to analyze, at scales of kilometers, the connectivity patterns of the inner-shelf larval fish species of Mallorca Island and how they are affected by wind-driven circulation. In particular, we focus our study on the dispersal patterns produced by dominant wind regimes clustered in two wind modes, their seasonal and inter-annual variations. The southern coast of the island extends for approximately 140 $\mathrm{km}$, including five coastal MPAs (two of them are considered to be a single MPA for the purposes of this paper). In formulating management decisions to protect the coastal ecosystems contained within these MPAs, it is important to understand the drivers of coastal recruitment and the level of exchange in networked MPAs; however, this issue remains unresolved to date. 


\section{METHODS}

\section{Study area}

For the purposes of this study, we assume that the southern Mallorca shelf is divided into an inner- and outer-shelf region. Although the outer shelf is influenced by ocean dynamics, the inner shelf is affected primarily by wind-induced processes. The sea bottom in this area is primarily covered by seagrasses (Posidonia oceanica) that can extend to a depth of $40 \mathrm{~m}$ with different extents of coverage (Duarte, 1991) and with interspersed sandy and rocky areas. Bays and coastal inlets provide refuge for juvenile fishes. Because of the ecological value of the island shelf, five marine protected areas have been established, including the National Park of Cabrera (Fig. 1). Two of these areas, Malgrats and Toro, are small and close together and, for the purpose of this paper, have been considered to be a single MPA. Further offshore, the bottom habitats are mainly sandy or mud.. During summer, the vertical motions are restricted by a strong seasonal thermocline that occurs at depths ranging from 30-40 $\mathrm{m}$ in the inshore and neritic waters.

One of the most conspicuous climatic features of Mallorca is wind seasonality. As is true over much of the western Mediterranean Sea, the most consistent winds during the winter-spring transition are derived from synoptic scale depressions that sweep west to east causing southwesterly winds. This situation continues to early May but diminishes in frequency and intensity as the influence of the Azores anticyclone extends to this region as summer approaches. The warmer days of spring result in a sea breeze regime that becomes gradually established by the end of May, although it can occur on warm days during winter. 
The sea breeze usually develops under anticyclonic situations, weak surface pressure gradients, intense solar radiation and clear skies (Ramis and Alonso, 1988). The wind vector direction varies around Mallorca with the topography of the island and the time of day; it generally presents midday southeasterly to southwesterly direction in the studied area (see Ramis et al., 1990).

Although the main patterns of regional scale circulation are well described (Millot, 1994; Garcia-Lafuente et al., 1995; López-Jurado et al., 1995, 1996; García-Ladona et al., 1996; Pinot et al., 2002) and the local circulation in some bays has been analyzed in detail (Basterretxea et al., 2004; Orfila et al., 2005; Basterretxea et al., 2007), less is known about the shelf-scale circulation, which is assumed to be weak and highly variable. Werner et al. (1993) identified the shelf circulation patterns off of southern Mallorca under idealized wind forcing. They described southeastward shelf circulation during winter storm conditions from WSW and locally variable currents under sea breeze forcing. Recently, Jordi et al. (2011) showed that the oscillatory motions associated with the presence of island trapped waves (ITWs) are a major feature of the coastal dynamics of Mallorca, accounting for approximately $70 \%$ of the low frequency variance on the shelf. Along linear coastlines, ITWs produce coast-parallel oscillatory motions with low net transport; however, non-linear interactions with topography can produce residual flows affecting the distribution of contaminants, particles and planktonic organisms. Because tidal forcing is low (spring range $<0.25 \mathrm{~m}$ ), both locally wind-forced transport and wind-generated ITWs are considered to be important contributors to fish larval dispersal patterns.

\section{Meteorological data and wind pattern classification}


For analyzing wind patterns, 12-hourly wind maps were constructed by optimal interpolation of wind data that was recorded by two coastal meteorological stations (Palma Airport and Cape Salines) and the QuikSCAT satellite for the study period (2000-2009). The resultant synoptic wind maps were classified using a self-organizing map (SOM) algorithm. The SOM is a non-linear cluster analysis tool based on a self-organizing mapping neural network, which has no supervision on its learning. It is designed for pattern recognition and classification (Kohonen, 1984, 1997) and identifies patterns in the input data, based on their underlying variance structure. The SOM algorithm computes the patterns or modes so that they optimally describe the domain of the observations. In recent years, SOMs have been widely used as pattern recognition tools in synoptic meteorology (Richardson et al., 2003; Liu and Weisberg, 2005; Mau et al., 2007). We used the MATLAB SOM toolbox developed by Vesanto et al. (2000). Compared with other common neural networks, SOMs demonstrate more powerful capabilities in classifying, recognizing and clustering wind patterns.

\section{Model implementation}

The hydrodynamics of southern Mallorca were simulated using a three-dimensional density-resolving model, based on the Princeton Ocean Model (POM). The resolution of the hydrodynamic model was $200 \mathrm{~m}$ in the horizontal, and its 25 non-equidistant (sigma) vertical layers were organized to enhance the resolution near the surface and the seabed. The flow fields produced by surface wind forcing were obtained from the 12-hourly wind maps for ten years (2000-2009). The results of the hydrodynamic computation were stored at hourly intervals and then used in a post-processing mode to drive a separate behavioral 
and particle-tracking model for the development and transport of fish eggs and larvae. A random walk term was used to approximate the effects of the sub-grid scale processes on particle trajectories (Xue et al., 2008). This random movement has a mean of zero and a variance of $2 \mathrm{~K}_{\mathrm{h}} \Delta \mathrm{t}$, where $\mathrm{K}_{\mathrm{h}}$ is a horizontal diffusivity constant set at $500 \mathrm{~m}^{2} \mathrm{~s}^{-1}$. Comparative tests were performed using a $\mathrm{K}_{\mathrm{h}}$ of $50 \mathrm{~m}^{2} \mathrm{~s}^{-1}$

We based our dispersal analysis on 10-year simulations (2000-2009) of 19,325 passive tracers that were released at weekly intervals from seagrass/rocky bottoms $(<40 \mathrm{~m}$ depth) for a 6-month season (March to August) each year. This period covers the spawning season of most Mediterranean coastal fish species (Tsikliras et al., 2010). Considering that the pelagic larval duration of Mediterranean coastal fish species typically ranges from 2 weeks (e.g Oblada melanura, Boops boops) to 4 weeks (e.g. Coris julis ) before settlement (Raventós and Macpherson, 2001), the tracers were released assuming a pelagic larval duration (PLD) of 3 weeks. Comparisons with 2- and 4-week releases were also performed. The particles were homogeneously distributed in the release areas (the seagrass-covered bottoms in Fig. 1) and were left to drift for the abovementioned time periods. The connectivity estimates were obtained by subdividing the inner-shelf into $25 \sim 6 \mathrm{~km}$ wide sectors following the coastline. Consistent with observations that the eggs and larvae of coastal species mainly occur near the surface (e.g., Olivar and Sabatés, 1997; Olivar et al., 2001), the depth of the release of the particles was random within the first $10 \mathrm{~m}$ of the water column. No patchiness was considered within each quadrant.

A reflective boundary condition was used to prevent particles from moving onto land. The eggs and larvae were treated as passive, neutrally buoyant particles, flowing near the surface. We assumed that during the first 3 weeks of age, transport of fish propagules is 
mainly driven by physical forces. Furthermore, as no information on individual behavior or mortality is available for the vast majority of species in the area, biological traits were not considered. We assumed individual larvae to have been recruited to a particular coastal area if they were found in the inner-shore habitat (defined by each the box area) at the end of the pelagic larval period. For the purpose of this paper, connectivity $(C)$ is defined as the number of particles arriving into box $i$ from box $j$ by the end of the prescribed PLD period divided by the number of particles initially released in zone $j$. We also defined retention capacity $(R C)$ as the number of particles remaining in box $j$ at the end of the prescribed PLD period divided by the number of particles initially released in box $j$.

To evaluate the model performance, we compared the results with current data obtained at 3 moorings, two in Palma Bay and one in Cape Salines (refer to Fig. 4 for mooring locations). In the three cases, bottom-mounted Nortek 1MHz Aquadopp profilers were deployed for 6-month periods at an approximate depth of $26 \mathrm{~m}$. ADCP 1 was moored from March to October 2007, and ADCP 2 and 3 were deployed from March 2009 to October 2009. Details of the model performance can be found in Jordi et al. (2011). The matching of the model-derived particle distributions with the observed fish larvae distribution, with particular emphasis on retention, was performed by analyzing the larval spatial patterns of a coastal resident species, Chromis chromis, obtained from field research cruises. This species is a coastal spawner with benthic eggs and pelagic larvae. Larval distribution maps were obtained for surveys conducted in Cabrera NP (July 2007, boxes 10 to 17) and Palma Bay (July 2010, boxes 4 to 8). Samples were gathered from hauls from standard bongo-nets with $335 \mu \mathrm{m}$ mesh equipped with flowmeters (General Oceanics model 230) and preserved in $2 \%$ sodium borate-buffered formalin. Standard length (SL, 
$\mathrm{mm}$ ) was measured from up to 30 random individuals from each station under a binocular microscope (precision=0.01 $\mathrm{mm}$ ). We analyzed the abundance of large larvae (size above population median value) for the two surveys. Based on the larval size at hatching and at four days of development provided by Padoa (1956) and the size at the age of newly settled individuals (Raventós and Macpherson, 2001), these larvae are at least a week in age. The assumption underlying this analysis is that larger larvae will accumulate in areas of higher retention. Despite these data only providing a general view of one of the wind situations analyzed (summer conditions), the high environmental stability during the surveys, which was typical for that period, and the abundance of the selected species suggest that the observed distributions may be a good proxy for an average summer distribution. 


\section{RESULTS}

\section{Wind patterns}

Only the first two patterns or modes derived from the application of the SOM algorithm to the wind maps were considered. These modes captured $79 \%$ of the total wind variability around Mallorca and allowed a simple interpretation of the seasonal variation. The frequency of occurrence of the other wind patterns is relatively low. The resulting averaged features of the synoptic field characterizing each mode are shown in Fig. 2. Mode 1 comprised north to northeasterly winds that were typically characteristic of the anticyclonic circulation that prevail in the summer. Mediterranean summers are warm and mostly dry due to the influence of a high-pressure ridge extending from the Azores subtropical high (Xoplaki et al., 2003). Although the effect of the local sea breeze was not captured in the QuickSCAT data, comparisons with the wind records at Palma Airport and Cape Salines revealed that it was associated with the situations of high atmospheric pressure included in mode 1 . Mode 2 mainly corresponded to the passage of low-pressure systems through the Iberian Peninsula, generating westerly and southwesterly winds.

As displayed in Fig. 3a (only the year 2007 is represented), both wind modes alternated throughout spring, and mode 1 became prevalent on summer. This seasonal shift in atmospheric conditions most frequently occurred in mid-June, but, in some years, summer conditions settled earlier (e.g., years 2000 and 2006). Although summer conditions were very similar among the years, the most noticeable interannual variability occurred during spring (Fig. 3 b and c). In particular, in the years 2001 and 2008, mode 2 winds were 
remarkably prevalent. Large scale weather patterns are known to have an impact on the intensity and frequency of Mediterranean cyclones.

\section{Wind-induced coastal circulation}

Coastal circulation obtained from the ADCP records reflected weak currents (mean vector velocity $\sim 1.4 \mathrm{~cm} \mathrm{~s}^{-1}$ ) with notable change in the drift direction between the spring and summer. This mean value was variable depending on the events included in the averaging period. Enhancement of the current intensity by $\sim 500 \%$ was observed in Cape Salines where ADCP1 is located (Fig. 4a). South and westward circulation was prevalent under mode 1 winds, whereas eastward drift was promoted under mode 2 forcing. These observations were in qualitative agreement with the model results, although somewhat more intense flow was obtained in the simulations (average difference of $0.7 \mathrm{~cm} \mathrm{~s}^{-1}$ ). Although we used the wind modes as depicted by the SOM for easy interpretation, the model was forced by real winds. Numerical comparisons of the averaged spatial patterns for both modes revealed significant changes on both sides of Cape Salines and generally weaker circulation under mode 1 forcing. Coastal drift flushed the water parallel to the coast in a clockwise direction under this mode and in the opposite direction for mode 2 (Fig. $4 \mathrm{~b}$ and c). The model solution generated a cyclonic gyre to the east of Cabrera and an area of weakened flow towards the northwest of Cabrera under mode 1 forcing. Conversely, sheltering and recirculation occurred to the lee of Cape Salines under mode 2 winds. Obviously, these mean patterns should not be considered to be stationary because the development and size of these gyres were dependent on the strength of the coastal forcing. 


\section{Simulated larval dispersal for modal winds}

To determine the effect of the two wind modes obtained by the SOM classification in the connectivity patterns of the study area, we analyzed the transport of particles during 3 week periods for episodes when the wind consistently corresponded to each wind mode, i.e., the occurrence of a specific mode is greater than the mean occurrence of this mode plus two times the standard deviation. The pattern obtained by this classification method is summarized in Fig. 5a and b. Under both wind-forcing scenarios, limited dispersal from spawning grounds was observed (low dispersion from the main diagonal of the matrix). Coherently with the current patterns, mode 1 produced westward dispersal along the western coast (sectors 1-13) and southward transport along the eastern coast, whereas dispersal in the opposite direction occurred under mode 2 winds. This reversal was particularly notable along the western coast, where differences of up to $6 \%$ were achieved. The generally lower energy of the mode 1 conditions also favored higher $(2-3 \%)$ selfrecruitment. This phenomenon had notable effects in the exchange among the MPAs, which was increased by the more dispersive mode 2 .

As shown in Fig. 5c, a slightly smeared version of the connectivity obtained for the two wind modes was obtained for the mean pattern of the 10 years analyzed. Self-

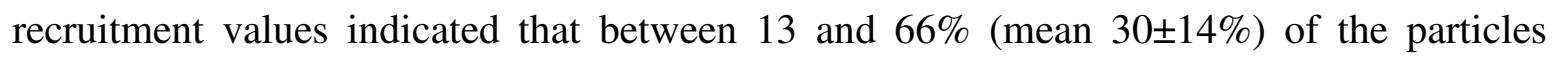
remained in the original zone 3 weeks after being released and that $30 \pm 10 \%$ were lost to unfavorable areas (boundary sectors excluded). The alternation of the wind forcing produced an isotropic diffusion with a low preferential direction of transport. The exceptions were primarily caused by the topographical features of the coast (e.g., between 
sectors 9 and 16). Moderate transport (i.e., >10\%) occurred primarily among contiguous cells, and the transport success to more distant areas was modest. Indeed, the significant connectivity (>1\%) oscillated between 20 and $30 \mathrm{~km}$ from the spawning areas.

The area with the highest retention corresponded to the inner part of Palma Bay (sectors 6 and 7), where currents were weakened by the coastal topography. Cabrera National Park also retained a significant percentage of particles (46 $\pm 4 \%$, MPA-4), which was attributed to the recirculation patterns produced in the coastal flow by the islands. However, low export was expected from this area. Conversely, the lowest retention (i.e., $<20 \%$ ) occurred in cells situated in the vicinity of capes (sectors $1,4,5,8$ and 17). MPAs 1 and 2, located within the boundaries of Palma Bay, primarily dispersed particles to other areas. In contrast, MPA-3 was a receptor of larvae that originated in other zones, particularly under mode 1 winds when sectors 17 and 18 contributed with up $43 \%$ of the particles arriving to this MPA. This is caused by the weakening of the coastal flow to the west of Cape Salines (see Fig. 4). As shown in Fig. 5d, the importance of this role as source or sink for larvae varied seasonally in all cases, except for MPA-4, for which seasonal differences are low.

\section{Inter-annual variations}

The inter-annual variations in wind forcing produced changes in the recruitment success, but the rank of importance in the connectivity with other areas rarely varied; the few times this occurred, the variations were among neighboring areas. Comparison of the spring dispersal among years, with the predominance of mode 2 winds in 2008 and mode 1 in 2003, revealed an increase in the east- and northward-directed connectivity, with the most 
notable differences along the eastern coast (sector 17 and above, Fig. 6a). Because mode 1 conditions typically prevailed in summer, when most of the littoral species spawned, the inter-annual variations between two years with either a high or low percentage of mode 1 winds (2005 and 2001) were explored. For those years, as expected, transport south and westward was emphasized, but a remarkable increase in the self-connectivity of MPA-4 was observed. Inter-annual variations had a significant effect on the self-recruitment of the system. The mean range of variation for the 10 years simulated was $10.8 \pm 4.1 \%$, but some areas, like sector 17 in the south of Cabrera, experienced variations of up to $18 \%$.

\section{Sensitivity analysis and comparison with field data}

A comparative test conducted using PLDs of 2 and 4 weeks yielded very low (not significant) but site-specific differences in long-distance connectivity and negligible variations in self-recruitment, which was mainly dictated by the diffusivity values. Conversely, variations in diffusivity had a major impact in the connectivity estimates, while maintaining the same connectivity pattern, as shown in Fig. 7. Retention was significantly higher and dispersal to nearby areas was lower, when a diffusivityvalue of $50 \mathrm{~m}^{2} \mathrm{~s}^{-1}$ was used. This suggests that in nearshore environments where $K_{h}$ is notably reduced larval retention would be above our estimated values.

The retention capacity estimates showed increased retention in Palma Bay (sectors 6 and 7) and in areas where topographically generated retention patterns were expected $(13,14$, and to a lesser extent 15, 16 and 21; Fig. 8a). In general, the larval distribution maps agreed with model results, yet some differences were observed (Fig. 8b and c). It should be noted that, although the model results indicated the average patterns, the field data corresponded 
with the episodic scenarios. The larval distribution maps confirmed that Palma Bay was a retentive area, although, unlike the model results, the larvae aggregated in the approximate center of the Bay and not along the inner coast. The accumulation at either side (southeastnorthwest) of Cabrera (MPA-4) was consistent with the alternation of the different wind modes along Cabrera. Nevertheless, this effect was not evident west from Cape Salines (sector 13), where the model results indicated a highly retentive area.

\section{DISCUSSION}

Our connectivity analysis revealed that weak and variable flow dynamics, together with topographically driven differences in the response of currents to wind changes, were the main determinants of high retention rates in southern Mallorca. The presence of topographic hot spots for larval retention emphasized the importance of small spatial scales (i.e., 20-30 km) to the demography of inner-shelf fish species. We estimated that an average of $30 \%$ of the spawned larvae remained in the source areas, allowing for their full development within the proximity of adult habitat. To understand the importance of this value to larval potential survival, several points must be considered. First, our model does not include larval mortality. Natural larval mortality before metamorphosis varies widely with temperature, growth, species, and/or patchiness, with values ranging from 1 to $50 \%$ day $^{-1}$ (Houde, 1989; McGurk, 1986). High egg mortality also occurs, although egg development lasts only for a few days (McGurk, 1986). Stage-duration depends mainly on the species and temperature, and the stage mortality will vary with the instantaneous 
mortality over the duration of the stage. Second, the size of the compartments used can influence the connectivity and self-recruitment results. This size depends on the species considered, its home range and spawning habits. Our interpretation is based on the fact that several key Mediterranean littoral species have a small home range ( $1 \mathrm{~km}$, March et al., 2010; Alós et al., 2011; Palmer et al., 2011), at least in their adult phase, which is within the order of magnitude of our selected compartments. The self-recruitment values of up to $70 \%$ observed herein are not particularly high considering the topography of the coast and the stability of the water mass. High self-recruitment values for a littoral Mediterranean species whose adults exhibit a small home range (Trypterigion delaisi) have been confirmed genetically (Carreras-Carbonell et al., 2007), and our results expand upon the hypotheses of strong larval self-recruitment patterns for littoral species. In tropical areas, high self-recruitment of coral-reef fish has been documented even in extremely small areas (Jones et al., 2005).

Growing evidence indicates the importance of self-recruitment in the early life stage success of coastal (Carreras-Carbonell et al., 2007), reef (Jones et al., 2005) and neritic populations (Churchill et al., 2011; see also reviews by Levin 2006 and Cowan and Sponaugle 2009). Although post-recruitment mortality may modify recruitment patterns, increased survival caused by self-replenishment may in turn influence survivorship to adulthood and self-maintenance of the population (Bradbury et al., 2008), particularly in oligotrophic systems, in which the export of larvae to the outer shelf would likely result in poor feeding conditions. Indeed, unlike open systems in which recruitment success may vary with changes in ocean dynamics, relying on local replenishment confers notable interannual adult population stability to inner-shelf species. This stability appears to be a 
common feature of coastal spawning organisms for which self-recruitment is high, as revealed by genetic and numerical dispersal studies (e.g., Lefebvre et al., 2003; Planes et al., 2008).

Self-recruitment along the inner shelf is enhanced by cross-shore shear and in the lees of topographic features such as capes and islands where increased primary and secondary productivity may create favorable foraging habitats (Rissik et al., 1997; Hamne and Hauri, 1981). Our simulations indicate that most inshore larval trapping is due to the rugged coastline that attenuates the flow near the coast, allowing larvae to remain within the original area. As expected, we obtained higher self-recruitment (more leptokurtic dispersal shape) than that predicted by Gaussian dispersal kernels for straight coastlines and uniform alongshore flows (Siegel et al., 2003). Advection to other areas is controlled by release from source environments due to diffusive motions. Therefore, increased dispersal to nearby areas is obtained at higher $K_{h}$ values while maintaining a similar connectivity pattern. Largier (2003) thoroughly reviewed the effect of diffusivity and its inshoreoffshore variations. He discussed the relevance of the exponential increase in $K y$ (crossshore diffusivity) from near the shore $\left(1-10 \mathrm{~m}^{2} / \mathrm{s}\right)$ to approximately $100 \mathrm{~m}^{2} / \mathrm{s}$ over the wind-driven shelf. Assuming similar values for our system, our estimates of dispersal would be conservative, and higher self-recruitment would be expected, as suggested by Fig. 7. Moreover, we have not considered the influence of larval behavior (i.e., swimming and sensory abilities), which depending on the species could either reduce dispersal and consequently favor self-recruitment (Cowen, 2002), or increase the exchange among fish populations. 
Arguably (see e.g., Farmer and Berg, 1990), the presence of eddies and other recirculating structures enhance larval retention, a well-known phenomenon observed in coastal flows (Signell and Geyer, 1991; Swearer et al., 1999) that may also thereby influence the productivity of the waters. Significant eddy formation was predicted in the model simulations in the vicinity of Cape Salines, to the west of Cabrera and, less prominently, in other coastal topographic irregularities. Eddies lasting for some hours have also been described in Palma Bay, affecting sectors 6 and 7 (Jordi et al. 2011). Although in some areas eddy formation may be caused by variations in Ekman drift, they are particularly associated with interactions between ITWs and the coast. In contrast to oceanic areas where eddies are weakly influenced by the dissipation of vorticity, in shallow water, the lifetime of eddies is relatively short because of the strong influence of bottom friction and the variability of wind forcing. Therefore, these eddies are not necessarily permanent, although they are common enough to be statistically significant, in particular under mode 1 winds. This phenomenon is consistent with the RC estimates shown in Fig. 8 (see also Fig. 4), where the areas affected by recurrent eddy presence suggested net larval retention, which is compatible with the results from the larval surveys. The topographically generated eddies with timescales of the same order as those of the PLDs could be effective in retaining fish larvae. Thus, the relatively reduced PLDs of summer spawners (Macpherson and Raventós, 2006) due to high water temperatures in that period, together with persistent mode 1 winds, would favor eddy trapping.

Ayata et al. (2010) compared the dispersal kernels and connectivity matrices among 16 populations of marine invertebrates and demonstrated a significant impact of PLD on the dispersal kernels. For all spawning months and the spawning populations, a shorter 
PLD resulted in shorter mean dispersal distances. On average, they found that a decrease of $50 \%$ in PLD (from 4 to 2 weeks) caused a decrease of $45 \%$ in mean dispersal distance. In addition, O'Connor et al. (2007) demonstrated a negative relationship between temperature and pelagic larval durations (PLDs) for a wide range of marine species. Reduced PLDs induced by temperature increases could lead to substantial modifications of dispersal and connectivity patterns. At first look, our results seem to contradict this relationship because in the time range considered (2-4 weeks), PLD seemed not to be critical for the dispersal range of these species in a variable forced system. However, this result is caused by the different timescales considered.

As Mitarai et al. (2008) stated, connectivity matrices are a function of several time scales, such as planktonic larval duration, the frequency and duration of larval release, and the inherent time scale of coastal circulation processes. We based our connectivity estimations on mean patterns rather than on specific wind episodes because, for larvae with relatively long PLDs, the importance of episodic events tends to diminish (Salomon, 1990; Thiébaut et al., 1994) and therefore larval dispersal is more related to mean meteorological conditions. In temperate areas with slow and unpredictable current conditions, spawning timing is not critical. Conversely, if the focus switches to areas with notable current shifts (e.g. Carson et al 2010) or to species with short spawning periods or to specific spawning pulses with scales close to atmospheric synopticity, the variations in PLD become critical. The association between settlement pulses and intense weather events is documented for a wide range of crustaceans (Johnson and Hester, 1989; Epifanio, 1995; Briones-Fourzan et al., 2008). Short and synchronous spawning events are typical for coral reef species (e.g., Tucker 1998), where advection is critical. 
On a seasonal basis, the variability in wind direction, together with oscillatory motions produced by ITWs, retained inner-shelf fish larvae close to the spawning grounds, favoring self-recruitment. Seasonality did not notably vary the connectivity pattern, but it does affect dispersion to other areas. Our data show that dispersive losses were reduced during the summer, when mode 1 winds consistently blew. Reduced wind variability (alternation between mode 1 and 2) also decreased in this season. Seasonal winds may directly influence the settlement success, either by reducing spawning success during periods of high winds and turbulent conditions or by enhancing the likelihood of coastal retention during periods of minimal wind (Johannes, 1978; Lobel, 1989; Colin, 1992). Changes in the wind regime affected transport and have also been related to the onset of spawning. For example, Thomson and Hourston (2011) related the initiation of sockeye salmon spawning to the weakening of wind forcing.

Despite the evidence that dispersal was often limited to small scales, our simulations suggest that a notable proportion $(\sim 30 \%)$ of larvae could be advected offshore. The fate of these larvae was unknown and, because of dilution, their contribution to the sustainment of the adult population was likely to be negligible. However, the potential recruitment of some of these individuals to remote areas was regulated by episodic processes rather than by mean flow and could episodically become significant. These successful events could be ecologically important because they could contribute to the replenishment of populations in remote areas and to the large-scale genetic exchange.

Implications for the existing MPAs 
For MPAs to be successful in the protection of marine populations, individual MPAs must either be self-sustaining or adequately connected to other MPAs via dispersal (Planes et al., 2009). The spatial scale over which populations are connected by larval dispersal is critical to the efficiency of MPA networks because protection usually increases with increasing MPA size or when MPA spacing is close enough to allow species persistence via network connectivity rather than self-replenishment (Moffit et al., 2011). If open populations do not buffer against local extinction, there is likely to be increased susceptibility to disturbance and localized fishing effort (Bradbury et al., 2008). Consequently, spatial management strategies that are based on networked no-take areas may be successful in enhancing and protecting local recruitment. However, a growing body of research highlights the evidence of restricted dispersal, questioning the paradigm that marine populations are demographically open at the spatial scales therein addressed (e.g., Jones et al., 1999; Swearer et al., 1999; Sotka et al., 2004; Leggett and Frank 2008). Considering that many coastal resident fish populations are characterized by localized population structure with limited dispersal and high self-recruitment, the networking of MPAs carried out in Southern Mallorca seems to be a reasonable approach for tackling conservation issues.

The size of individual reserves and the placement and distance between the reserves within the network will depend on the patterns of larval dispersal and the connectivity among the populations (Stobutzki, 2001). Apostolaki et al. (2002) stated that the greatest success in MPAs is observed for species that occupy discrete habitats in which the required habitats are in close proximity, such as when spawning habitats overlap larval/juvenile nursery 
areas. Coastal fishery management for Majorca Island is an example of a complex system in which the combined use of MPAs with other measures operating on the recreational and commercial fleet may be the only way of sustaining both conservation and marine use by multiple users (Morales-Nin et al., 2010). However, too often the implementation of these measures has not been coordinated (nor evaluated) under single or multiple objective schemes.

In our case, the four MPAs considered can be essentially grouped in two clusters with different characteristics based on coastal hydrography. MPA-1 and 2 are characterized by higher dispersal rates because of their locations in areas of enhanced flow (next to prominent capes). In contrast, MPA-3 and 4 are high-retention areas, favoring the recruitment of larvae from other zones. From a conservation perspective, both roles present interest, but the premises for their effective design are different. Populations in MPAs located in retention areas display a strong self-recruitment component. Assuming that coastal resident species present a small home range (proven only for adults of some species) and the low mean dispersal herein reported, population persistence would be guaranteed at these sites. The Area of Cabrera National Park harbors high species richness and abundance/biomass of fishes (Reñones et al., 1997; Harmelin-Vivien et al., 2008) being a potential important spawning area for targeted fishery species (Crec'hriou et al., 2010). Some vulnerable species in the area, like dusky grouper (Epinephelus marginatus), appear to be very sensitive to protection levels and show high biomass and broad size structure suggesting that the population is self-recruiting (Reñones et al., 1999). The geographical location of this MPA provides the adequate environmental setting to generate retention 
areas (thus favoring larval development and acquisition of behavioural properties that promote survival).One notable difference between these two MPAs (3 and 4) is that alongshore exchange is expected in MPA-3, whereas because of its relatively isolated nature, MPA-4 is less likely to seed other areas. This low dispersal from islands to the mainland has been previously observed in other areas and suggests that islands are less effective in enhancing fisheries (the other objective of MPAs) through larval export (Williamson et al., 2004; Bell, 2008). For MPAs promoting high dispersion, their effectiveness relies on networking with other MPAs or with unprotected zones that offer suitable nursery habitats. In Mallorca, our estimates show that the required distance for those connections is $20-30 \mathrm{~km}$. This requirement is met by MPA-1 and 2, which might effectively replenish the nearby Bay of Palma, where most of the recreational fishing effort is concentrated (Morales et al., 2005).

In summary, we provide evidence of i) the relatively high rates of potential self-recruitment in the coastal areas of a Mediterranean Island and how environmental features are linked with connectivity values and ii) how established small-scale MPAs in close proximity to one another in a coastal Mediterranean zone serve different functions in either exporting or retaining capacity. This information is essential because the degree of connectivity among the MPAs sets the scale at which management strategies for exploited species need to be applied.

\section{ACKNOWLEDGMENTS.}


This work was founded by TALACA project PN 38/2005. A. Jordi's work was supported by a Ramón y Cajal grant from MICINN. The SOM toolbox for MATLAB was created by Juha Vesanto, Johan Himberg, Esa Alhoniemi, and Juha Parhankangas and is available at http://www.cis.hut.fi/projects/somtoolbox/. 


\section{REFERENCES}

Agostini, V.N. and Bakun, A. (2002) 'Ocean triads' in the Mediterranean Sea: physical mechanisms potentially structuring reproductive habitat suitability (with example application to European anchovy, Engraulis encrasicolus ). Fisheries 11:129-142.

Almany, G.R., Connolly, S.R., Heath, D.D., Hogan, J.D., Jones, G.P., McCook, L.J., Mills, M., Pressey, R.L. and Williamson, D.H. (2009) Connectivity, biodiversity conservation, and the design of marine reserve networks for coral reefs. Coral Reefs 28:339-351.

Alós, J., March, D., Palmer, M., Grau, A. and Morales-Nin, B. (2011) Spatial and temporal patterns in Serranus cabrilla habitat use in the NW Mediterranean revealed by acoustic telemetry. Mar. Ecol. Progr. Ser. 427: 173-186.

Ayata S.D., Lazure, P. and Thiébaut E. (2010) How does the connectivity betweenpopulations mediate range limits of marine invertebrates ? A case study of larval dispersal between the Bay of Biscay and the English Channel (North-East Atlantic). Prog. Oceanogr. 87:18-36.

Bailey, K.M. (1981) Larval transport and recruitment of Pacific hake Merlucius productus. Mar. Ecol. Prog. Ser. 6:1-9.

Basterretxea, G., Garcés, E., Jordi, A., Anglès, S. and Masó, M. (2007) Modulation of nearshore harmful algal blooms by in situ growth rate and water renewal. Mar. Ecol. Prog. Ser. 352:53 -65.

Basterretxea, G., Orfila, A., Jordi, A., Casas, B., Lynett, P., Liu, P.L.F., Duarte, C.M. and Tintoré, J. (2004) Seasonal dynamics of a microtidal pocket beach with Posidonia oceanica seabeds (Mallorca, Spain). J. Coastal Res. 20:1155- 1164.

Bell, J.J. (2008) Connectivity between island Marine Protected Areas and the mainland. Biol. Conserv. 141:2807-2820.

Bradbury, I.R. and Snelgrove, P.V.R. (2001) Contrasting larval transport in demersal fish and benthic invertebrates : the role of behavior and advective processes in determining spatial pattern. Can. J. Fish. Aquat. Sci. 58: 811-823.

Bradbury, I.R., Laurel, B.J., Robichaud, D., Rose, G.A., Snelgrove, P.V.R., Gregory, R.S., Cote, D., and Windle, M.J.S. (2008) Discrete spatial dynamics in a marine broadcast spawner: reevaluating scales of connectivity and habitat associations in Atlantic cod (Gadus morhua L.) in coastal Newfoundland. Fish. Res. 91:299-309.

Briones-Fourzan, P., Candela, C. and Lozano-Alvarez, E. (2008) Postlarval settlement of the spiny lobster Panulirus argus along the Caribbean coast of Mexico: Patterns, influence of physical factors, and possible sources of origin. Limnol. Oceanogr. 53: 970-985. 
Carreras-Carbonell, J., Macpherson, E. and Pascual, M. (2007) High self-recruitment levels in a Mediterranean littoral fish population revealed by microsatellite markers. Mar. Biol. 151:719 -727.

Carson, H. S., López-Duarte, P. C., Rasmussen, L., Wang, D., \& Levin, L. A. (2010). Reproductive timing alters population connectivity in marine metapopulations. Current biology 20:1926-1031.

Churchill, J.H., Rung, J. and Chen, C. (2011). Processes controlling retention of springspawned Atlantic cod (Gadus morhua) in the western Gulf of Maine and their relationship to an index of recruitment success. Fish. Oceanogr. 20:32-46.

Colin, P.L. (1992) Reproduction of the Nassau grouper, Epinephelus striatus (Pisces: Serranidae) and its relationship to environmental conditions. Env. Biol. Fish. 34:357-377.

Cooke, S. J. and Cowx, I.G. (2004) The role of recreational fisheries in global fish crisises. BioScience 54:857-859.

Cowen, R.K. (1985) Large pattern of recruitment by the labrid, Semicossyphus pulcher: causes and implications. J. Mar. Res. 43:719-742.

Cowen, R.K. (2002) Oceanographic influences on larval dispersal and retention and their consequences for population connectivity. In: Coral Reef Fishes. Dynamics and Diversity in a Complex Ecosystem. P.F. Sale (ed.) San Diego: Academic Press, pp. 149-170

Cowen, R.K., Hare, J.A., Cowen, R.K., Paris, C.B., Olson, D.B. and Fortuna, J.L. (2003) The role of long distance dispersal versus local retention in replenishing marine populations. J. Gulf Carib. Sci. 14:129-137.

Cowen, R.K. and Sponaugle, S. (2009) Larval dispersal and marine population connectivity. Ann. Rev. Mar. Sci. 1:443-466.

Crec'hriou, R., Alemany, F., Roussel, E., Chassanite, A., Marinaro, J.Y., Mader, J., Rochel, E. and Planes, S. (2010) Fisheries replenishment of early life taxa: potential export of fish eggs and larvae from a temperate marine protected area Fish. Oceanogr. 19: 135-150.

Cury, P. and Roy, C. (1989) Optimal environmental window and pelagic fish recruitment success in upwelling areas. Can. J. Fish. Aquat. Sci. 46:670-680.

Duarte, C.M. (1991) Seagrass depth limits. Aquat. Bot. 40:363-377

Epifanio, C.E. (1995) Transport of blue crab (Callinectes sapidus) larvae in the waters off mid-Atlantic States. Bull. Mar. Sci. 57:713-725. 
Farmer, M.W. and Berg, C.J.Jr. (1990) Circulation around islands, gene flow, and fisheries management. Proc. Gulf Caribb. Fish. Inst. 39:318-330.

García-Ladona, E., Castellón, A., Font, J. and Tintoré , J.(1996) The Balearic current and volume transports in the Balearic basin. Oceanol. Acta 19: 489-497.

García-Lafuente, J.M., López-Jurado, J.L., Cano, N., Vargas, M. and Aguiar, J. (1995) Circulation of water masses through the Ibiza channel. Oceanol. Acta 18:245-254.

Gell, F.R. and Roberts, C.M. (2003) Benefits beyond boundaries: The fishery effects of marine reserves. Trends Ecol. Evol. 18:448-455.

Goñi, R., Polunin, N.V.C. and Planes, S. (2000) The Mediterranean: marine protected areas and the recovery of a large marine ecosystem. Environ. Conserv. 27: 95-97.

Hamilton, S.L., Regetz, J. and Warner, R.R. (2008) Postsettlement survival linked to larval life in a marine fish. Proc. Natl. Acad. Sci. 105:1561-1566.

Hamne, W.M. and Hauri, I.R. (1981). Effects of island mass: Water flow and plankton pattern around a reef in the Great Barrier Reef lagoon, Australia. Limnol. Oceanogr. 26: 1084-1102.

Harmelin-Vivien, M., Le Diréach, L. Bayle-Sempere, J., Charbonnel, E., García-Charton, J.A., Ody, D., Pérez-Ruzafa, A., Reñones, O, Sánchez-Jerez, P., Valle, C. (2008). Gradients of abundance and biomass across reserve boundaries in six Mediterranean marine protected areas: Evidence of fish spillover? Biol. Conserv. 141: 1829-1839.

Hastings, A. and Botsford, L.W. (2006) Persistence of spatial populations depends on returning home. Proc. Natl. Acad. Sci. 103:6067-6072.

Hinckley, S., Hermann, A.J. and Megrey, B.A. (1996) Development of a spatial explicit, individual-based model of marine fish early life history. Mar. Ecol. Prog. Ser. 139: 47-68.

Hinrichsen, H.H., Bottcher, U., Koster, F.W., Lehmann, A. and St John, M.A. (2003) Modelling the influences of atmospheric forcing conditions on Baltic cod early life stages: distribution and drift. J. Sea Res. 49:187-201.

Houde, E.D. (1989) Comparative growth, mortality and energetics of marine fish larvae: temperature and implied latitudinal effects. U.S. Fish. Bull. 87:471-495.

Howard, R.K., Edgar, G.J. and Hutchings, P.A. (1989) Faunal assemblages of seagrass beds. In: Biology of seagrasses: a treatise on the biology of seagrasses with special reference to the Australian region. Larkum, A.W.D., McComb, A.J. and Shepherd, S.A. (eds) Amsterdam. Elsevier, pp. 536-564.

Johannes, R.E. (1978) Reproductive strategies of coastal marine fishes in the tropics. Environ. Biol. Fishes. 3:65-84. 
Johnson, D.R. and Hester, B.S. (1989) Larval transport and its association with recruitment of blue crabs to Chesapeake Bay. Estuar. Coast. Shelf. Sci. 28:459-472.

Jones, G.P., Milicich, M.I., Emslie, M.J. and Lunow, C. (1999) Self-recruitment in a coral reef fish population. Nature 402: 802-804.

Jones, G.P., Planes, S. and Thorrold, S.R (2005) Coral reef fish larvae settle close to home. Curr. Biol. 15:1314-1318.

Jones, G.P., Srinivasan, M. and Almany, GR. (2007) Population Connectivity and Conservation of Marine Biodiversity. Oceanography 20: 42-53.

Jordi, A., Basterretxea, G. and Wang, D.-P. (2011) Local versus remote wind effects on the coastal circulation of a microtidal bay in the Mediterranean Sea. J. Mar. Syst. doi:10.1016/j.jmarsys.2011.05.007

Kingsford, M.J. and Suthers, I.M. (1994) Dynamic estuarine plumes and fronts: importance to small fish and plankton in coastal waters of NSW, Australia. Cont. Shelf Res. 14:655-672.

Kingsford, M.J. and Finn, M. (1997) The influence of phase of the moon and physical processes on the input of presettlement fishes to coral reefs. J. Fish Biol. 51:176205.

Knutsen, H., Olsen, E.M., Ciannelli, L., Espeland, S.H., Knutsen, J.A., Simonsen, J.H., Skreslet, S. and Stenseth, N.C. (2007) Egg distribution, bottom topography and small-scale cod population structure in a coastal marine system. Mar. Ecol. Prog. Ser. 333: 249-255.

Kohonen, T. (1984) Self-Organization and Associative Memory. Berlin: Springer Verlag. $312 \mathrm{pp}$.

Kohonen, T. (1997) Self-organizing maps. Berlin: Springer Verlag. 501pp.

Largier, J. (2003) Considerations in estimating larval dispersal distances from oceanographic data. Ecol. Appl. 13:71-89.

Laurel, B.J. and Bradbury, I.R. (2006) "Big" concerns with high latitude marine protected areas (MPAs): trends in connectivity and MPA size. Can. J. Fish. Aquat. Sci. 63:2603-2607.

Lefebvre A., Ellien C., Davoult D, Thiébaut, E. and Salomon, J.C. (2003) Pelagic dispersal of the brittle-star Ophiothrix fragilis larvae in a megatidal area (English Channel, France) examined using an advection/diffusion model. Est. Coast. Shelf Sci. 57:421-433.

Leggett, W. and Frank, K.T. (2008) Paradigms in fisheries oceanography. Oceanogr. Mar. Biol. 46:331-363. 
Leis, J.M. (2007) Behaviour as input for modelling dispersal of fish larvae: behaviour, biogeography, hydrodynamics, ontogeny, physiology and phylogeny meet hydrography. Mar. Ecol. Prog. Ser. 347:185-193.

Leis, J.M. (2010). Ontogeny of behaviour in larvae of marine demersal fishes. Ichthyol. Res. 57:325-342.

Levin, L.A. (2006). Recent progress in understanding larval dispersal: new directions and digressions. Integr. Comp. Biol. 46:282-297.

Liu, Y. and Weisberg, R.H. (2005) Patterns of ocean current variability on the West Florida Shelf using the self-organizing map. J. Geophys. Res. 110, C06003. doi:10.1029/2004JC002786.

Lobel, P.S . (1989) Ocean current variability and the spawning season of Hawaiian reef fishes . Env. Biol. Fish. 24:161-171.

López-Jurado, J.L., García-Lafuente, J., Pinot, J.M. and Alvarez, A. (1996) Water exchanges in the Balearic Channels, In: Dynamics of Mediterranean Seas. F. Briand (ed.). $221 \mathrm{pp}$.

Macpherson, E. and Raventós, N. (2006). Relationship between pelagic larval duration and geographic distribution of Mediterranean littoral fishes. Mar. Ecol. Prog. Ser. 327: 257-265.

Macpherson, E. (1998) Ontogenetic shifts in habitat use and aggregation in juvenile sparid fishes. J. Exp. Mar. Biol. Ecol. 220: 127-150.

March, D., Palmer, M., Alós, J., Grau, A. and Cardona, F. (2010) Short-term residence, home range size and diel patterns of the painted comber Serranus scriba in a temperate marine reserve. Mar. Ecol. Prog. Ser. 400:195-206.

March, D., Alós, J., Grau, A. and Palmer, M. (2011) Short-term residence and movement patterns of the annular seabream Diplodus annularis in a temperate marine reserve. Est. Coast. Shelf Sci. 92: 581-587.

Mau, J.-C.; Wang, D.-P., Ullman, D. S. and Codiga, D. L. (2007). Comparison of observed (HF radar, ADCP) and model barotropic tidal currents in the New York Bight and Block Island Sound. Est. Coast. Shelf Sci. 72:129-137.

McGurk, M.D. (1986) Natural mortality of marine pelagic fish eggs and larvae: role of spatial patchiness. Mar. Ecol. Progr. Ser. 34:227-242.

Millot, C. (1994) Models and data: a synergetic approach in the western Mediterranean Sea. In: Ocean Processes in Climate Dynamics: Global and Mediterranean Examples. Malanotte-Rizzoli, P. and Robinson, A. R. (eds) Amsterdam: Kluwer, pp. 407-425. 
Mitarai, S., Siegel, D.A. and Winters, K.B. (2008) A numerical study of stochastic larval settlement in the California Current system. J. Mar. Syst. 69:295-309.

Moffitt, E.A., White, J.W. and Botsford, L.W. (2011) The utility and limitations of size and spacing guidelines for designing marine protected area (MPA) networks . Biol. Cons. 144:306-318.

Morales-Nin, B., Grau, A.M. and Palmer, M. (2010). Managing coastal zone fisheries: A Mediterranean case study. Ocean Coast. Manage. 53:99-106.

Morales-Nin, B., Moranta, J., García, C., Tugores, M. P., Grau, A. M., Riera, F. and Cerdà , M. (2005). The recreational fishery off Majorca Island (western Mediterranean): Some implications for coastal resource management. ICES J. Mar. Sci. 62:727-739.

Myers, R.A. and Drinkwater, K.F. (1988) Offshore ekman transport and larval fish survival in the Northwet Atlantic. Biol. Oceanogr. 6:45-64.

Norcross, B.L. and Shaw, R.F. (1984) Oceanic and estuarine transport of fish eggs and larvae: a review. Trans. Am. Fish. Soc. 113: 153-165.

O’Connor, M.I., Bruno, J.F., Gaines, S.D., Halpern, B.S., Lester, S.E., Kinlan, B.P. and Weiss, J.M. (2007) Temperature control of larval dispersal and the implications for marine ecology, evolution and conservation. Proc. Natl. Acad. Sci. 104:1266-1271

Olivar, M.P., Salat, J. and Palomera, I. (2001) Comparative study of the spatial distribution patterns of the early stages of anchovy and pilchard in the NW Mediterranean Sea. Mar. Ecol. Prog. Ser. 217:111-120.

Olivar, M.P and Sabatés, A. (1997). Vertical distribution of fish larvae in the north-west Mediterranean Sea in spring. Mar. Biol. 129: 289-300.

Orfila, A., Jordi, A., Basterretxea, G., Vizoso, G., Marbà, N., Duarte, C.M., Werner, F.E. and Tintoré, J. (2005) Residence time and Posidonia oceanicain Cabrera Archipelago National Park, Spain. Cont. Shelf Res. 25:1339-1352.

Padoa, E. (1956) Sottordine Chromides. In: Uova, larvae e stadi giovanili di Teleostei. Fauna e Flora del Golfo di Napoli. D’ Ancona, U., Bertolini, F., Montalenti, G., Padoa, E., Ranzi, S., Sanzo, A., Sparta, A., Tortonese, E., Vialli, M. (eds), Edizione della Stazione Zoologica di Napoli, Monografia 38, pp. 573- 576.

Palmer, M., Balle, S., March, D., Alós, J. and Linde, M. (2011). Estimating the size of circular home range from fish Mark-Release-(single)-Recapture data: the case of a small labrid targeted by recreational fishery. Mar. Ecol. Prog. Ser. 430:87-97.

Pedersen, O. P., Slagstad, D. and Tande, K.S. (2003). Hydrodynamic model forecasts as a guide for process studies on plankton and larval fish. Fish. Oceanogr. 12:369-380. 
Pineda, J., Hare, J.A. and Sponaugle, S. (2007) Larval dispersal and transport in the coastal ocean and consequences for population connectivity. Oceanography 20:22-39.

Pinot, J.M., López-Jurado, J. L. and Riera, M. (2002) The CANALES experiment (19961998). Interannual, seasonal and mesoscale variability of the circulation in the Balearic Channels. Prog. Oceanog. 55:335-370.

Planes, S., Jones, G.P. and Thorrod, S.R. (2009). Larval dispersal connects fish populations in a network of marine protected areas Proc. Natl. Acad. Sci. 106: 5693-5697.

Ramis, C. and Alonso, S. (1988) Sea breeze convergence line in Mallorca. A satellite observation. Weather 43:288-293.

Ramis, C., Jansá , A. and Alonso, S. (1990) Sea breeze in Mallorca. A numerical study. Meteorol. Atmos. Phys. 42:249-258.

Raventós, N. and Macpherson, E. 2001. Planktonic larval duration and settlement marks on the otoliths of Mediterranean littoral fishes. Mar. Biol. 138:1115-1120.

Reñones, O., Moranta, J., Coll, J., Morales-Nin, B. 1997. Rocky bottom fish communities of Cabrera Archipelago National Park (Mallorca, Western Mediterranean). Sci. Mar. 61: 495-506.

Reñones, O., Goñi, R., Pozo, M., Deudero, S. and Moranta, J. 1999. Effects of protection on the demographic structure and abundance of Epinephelus marginatus (Lowe, 1834). Evidence from the Cabrera Archipelago National Park (West Central Mediterranean). Mar Life 9:45-53

Richardson, A.J., Risien, C. and Shillington, F.A., 2003. Using self-organizing maps to identify patterns in satellite imagery. Prog. Oceanogr. 59: 223-239.

Rissik, D. Suthers, I.M. and Taggart, C.T. 1997. Enhanced zooplankton abundance in the lee of an isolated reef in the south Coral Sea: the role of flow disturbance. J. Plank. Res. 19: 1347-1368

Roberts, C.M. (1997). Connectivity and management of Caribbean coral reefs. Science 278: $1454-1457$.

Roughgarden, J., Gaines, S. and Possingham, H. (1988) Recruitment dynamics in complex life cycles. Science 241:1460-1466.

Sala, E., Aburto-Oropeza, O., Paredes, G., Parra, I., Barrera, J.C. and Dayton, P.K. (2002) A general model for designing networks of marine reserves. Science 298:19911993.

Sale, P.F., Cowen, R.K., Danilowicz, B.S., Jones, G.P., Kritzer, J.P., Lindeman, K.C., Planes, S., Polunin, N.V.C., Russ, G.R. and Sadovy, Y.J. (2005) Critical science gaps impede use of no-take fishery reserves. Trends Ecol. Evol. 20:74-80. 
Salomon, J.C. (1990) Role of instantaneous and long-term water movements on the recruitment and life of benthic fauna in the English Channel. La mer 28:211-217.

Shenker, J.M., Maddox, E.D., Wishinski, E., Pearl, A., Thorrold, S.R. and Smith, N. (1993) Onshore transport of settlement-stage Nassau grouper Epinephelus striatus and other fishes in Exuma Sound, Bahamas. Mar. Ecol. Prog. Ser. 98:31-43.

Siegel, D.A., Kinlan, B.P., Gaylord, D. and Gaines, S.D. (2003) Lagrangian descriptions of marine larval dispersion. Mar. Ecol. Prog.Ser. 260: 83-96.

Signell, R.P. and Geyer, W.R. (1991) Transient Eddy Formation Around Headlands. J. Geophys. Res. 96:2561-2575.

Sinclair, M. (1988) Marine Populations: an Essay on Population Regulation and Speciation. Seattle: University of Washington Press, 252pp.

Sotka, E.E., Wares, J.P., Barth, J.A., Grosberg, R.K. and Palumbi, S.R. (2004) Strong genetic clines and geographical variation in gene flow in the rocky intertidal barnacle Balanus glandula. Mol. Ecol. 13:2143-2156

Sponaugle, S. and Cowen, R.K. (1996) Nearshore patterns of coral reef fish larval supply to Barbados, West Indies. Mar. Ecol. Prog. Ser. 133:13-28.

Stobutzki, I.C. (2001) Marine reserves and the complexity of larval dispersal. Rev. Fish Biol. Fisher. 10:515-518.

Swearer, S.E., Caselle, J.E., Lea, D.W. and Warner, R.R. (1999) Larval retention and recruitment in an island population of a coral-reef fish, Nature 402: 799-802.

Thiébaut, E., Dauvin, J.C. and Lagadeuc, Y. (1994). Horizontal distribution and retention of Owenia fusiformis larvae (Annelida: Polychaeta) in the Bay of Seine. J. Mar. Biol. Assoc. UK 74:129-142.

Thomson, R. E. and Hourston, R.A.S. (2011) A matter of timing: the role of ocean conditions in the initiation of spawning migration by late-run Fraser River sockeye salmon (Oncorhynchus nerka). Fish. Oceanogr. 20:47-65.

Tsikliras, A.C., Antonopoulou, E. and Stergiou, K. (2010) Spawning period of Mediterranean marine fishes. Rev. Fish Biol. Fisher. 20:499-538.

Tucker, J. (1998) Marine Fish Culture. Boston: Kluwer Academic Publishers, 750 pp.

Vermeij, M.J., Marhaver, K.L., Huijbers, C.M., Nagelkerken, I. and Simpson, S.D. (2010) Coral larvae move toward reef sounds. PLOS ONE 5: doi: 10.1371/journal.pone.0010660.

Vesanto, J., Himberg, J., Alhoniemi, E. and Parhanangas, J. (2000) SOM toolbox for Matlab 5, report. Helsinki University of Technology, Finland. 
Vigliola, L., Harmelin-Vivien, M.L., Biagi, F., Galzin, R., Garcia-Rubies, A., Harmelin, J.G., Jouvenel, J.Y., Le Direach-Boursier, L., Macpherson, E. and Tunesi, L. (1998) Spatial and temporal patterns of settlement among Diplodus sparid fishes in the northwestern Mediterranean. Mar. Ecol. Prog. Ser. 168: 45-56.

Vikebø, F., Jorgensen, C., Kristiansen, T. and Fiksen, O. (2007) Drift, growth, and survival of larval Northeast Arctic cod with simple rules of behaviour. Mar. Ecol. Prog. Ser. 347: 207-219.

Werner, F.E., Viúdez, A. and Tintoré, J. (1993) An explanatory study of the currents off the

southern coast of Mallorca including the Cabrera Island Complex. J. Mar. Sys. 4: 45-66.

Williamson, D.H., Russ, G.R. and Ayling, A.M. (2004) No-take marine reserves increase abundance and biomass of reef fish on inshore fringing reefs of the Great Barrier Reef. Environ. Cons. 31:149-159.

Xoplaki, E., Gonzalez-Rouco, J.F., Luterbacher, J. and Wanner, H (2003) Mediterranean summer air temperature variability and its connection to the larege-scale atmospheric circulation and SSTs. Clim. Dynam. 20:723-739. 


\section{FIGURE LEGENDS}

Figure 1. Bathymetric map showing the location of the study area along the southern coast of Mallorca (see inset for location). The areas shaded in green indicate the presence of seagrass meadows or rocky bottoms that determined the particle release points. The sectors used for dispersal calculations are indicated. The four MPAs referred to in the text are colored in yellow. MPA-1, Malgrats-Toro, includes 2 nearby small protected areas that have been considered as a single MPA for the purpose of this paper.

Figure 2. Mode 1 (a) and Mode 2 (b) regional wind patterns as depicted from the selforganizing map (SOM) classification of the interpolated wind data recorded by two coastal meteorological stations (Palma Airport and Ses Salines) and the QuikSCAT satellite data for the period (2000-2009).

Figure 3. (a) The spring-summer variation in the mode winds for 2007 obtained from the mean daily pattern classification. The transition between spring and summer conditions is indicated with a dotted line. (b) The interannual variations in the frequencies of the characterized wind clusters during spring (March-May) and (c) summer (June-August).

Figure 4 (a) Mean mode 1 (black) and mode 2 (gray) currents as obtained from ADCP records and (b) mean model-generated surface currents for mode 1 and (c) mode 2 winds. Note that the vector scale in panel (a) has been enlarged for clarity.

Figure 5. The connectivity matrix expressed as the $\%$ of particles released from each of the zones on the $x$-axis arriving in zones on the y-axis. The color indicates the percentage of the larvae from a source location arriving at a destination location at the end of the larval development period ( 3 weeks). The dashed line represents self-recruitment. (a) The connectivity matrix for persistent mode 1 episodes and (b) mode 2 winds. (c) The 10-year mean connectivity for the period considered and (d) seasonal differences (summer-spring). Note that the color bar for panels a, b and $\mathrm{c}$ is logarithmic (upper left). Black boxes indicate the seasonal changes in the dispersal from/to the four MPAs shown in Fig. 1.

Figure 6. Variation in the connectivity matrix between years with different wind mode percentages. (a) Spring variations between 2008 and 2003 and (b) summer differences for 2005 through 2001. 
Figure 7. Box-whisker plot (median line, 25\% and 75\% quantiles box, 5\% and 95\% quantiles whiskers) of the percentage of self-recruitment of the particles and those lost from the habitat for different diffusivity values $\left(\mathrm{m}^{2} \mathrm{~s}^{-1}\right)$.

Figure 8. (a) RC (\%) for spring and summer in the different sectors of the study region. The sign indicates either negative or positive balance between export and recruitment. (b) The distribution of large-sized larvae of Chromis chromis in Palma Bay and around Cabrera (c) in surveys conducted in July 2010 and 2007, respectively. Units are ind. $10 \mathrm{~m}^{-2} . R C$ is defined as the number of particles remaining in box $j$ at the end of the prescribed PLD period divided by the number of particles initially released in box $\mathrm{j}$. 


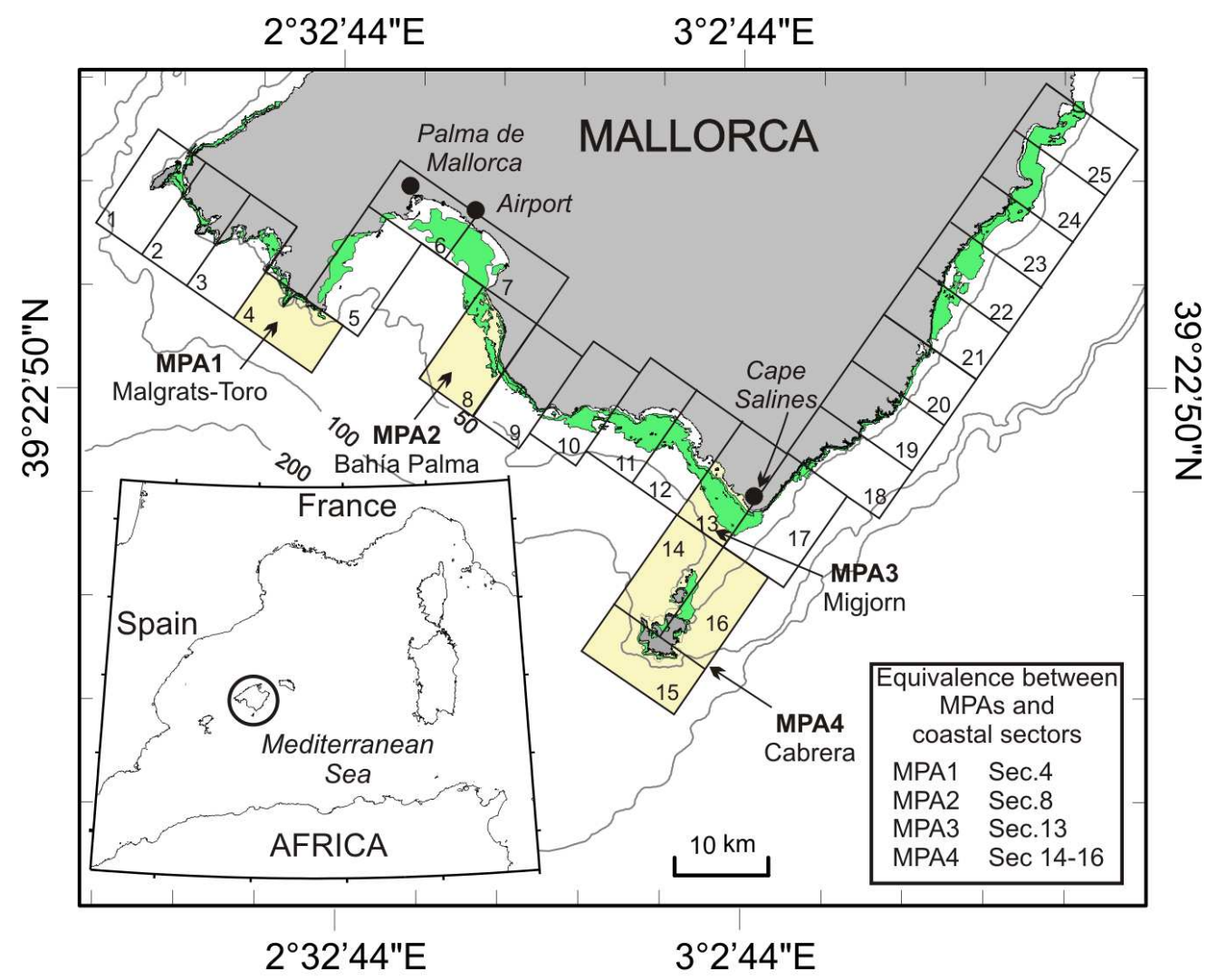

Figure 1

Figure 8. (a) RC (\%) for spring and summer in the different sectors of the study region. The sign indicates either negative or positive balance between export and recruitment. (b) The distribution of large-sized larvae of Chromis chromis in Palma Bay and around Cabrera (c) in surveys conducted in July 2010 and 2007, respectively. Units are ind. $10 \mathrm{~m}-2$. 


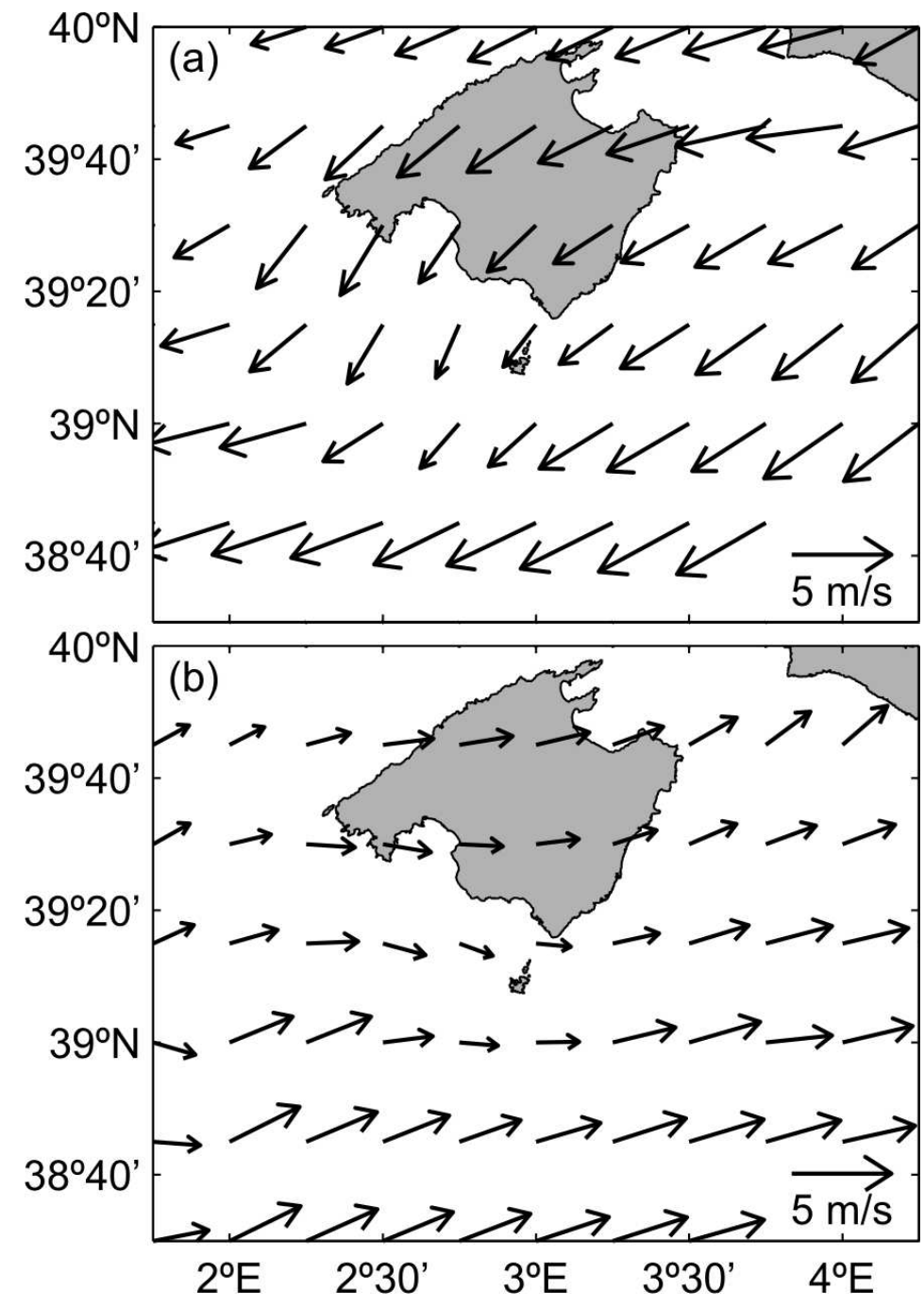

Figure 2

Figure 2. Mode 1 (a) and Mode 2 (b) regional wind patterns as depicted from the self-organizing map (SOM) classification of the interpolated wind data recorded by two coastal meteorological stations (Palma Airport and Ses Salines) and the QuikSCAT satellite data for the period (20002009)

$75 \times 124 \mathrm{~mm}(300 \times 300$ DPI $)$ 


\section{Figure 3}

Figure 3. (a) The spring-summer variation in the mode winds for 2007 obtained from the mean daily pattern classification. The transition between spring and summer conditions is indicated with a dotted line. (b) The interannual variations in the frequencies of the characterized wind clusters during spring (March-May) and (c) summer (June-August). $87 \times 106 \mathrm{~mm}(300 \times 300 \mathrm{DPI})$ 

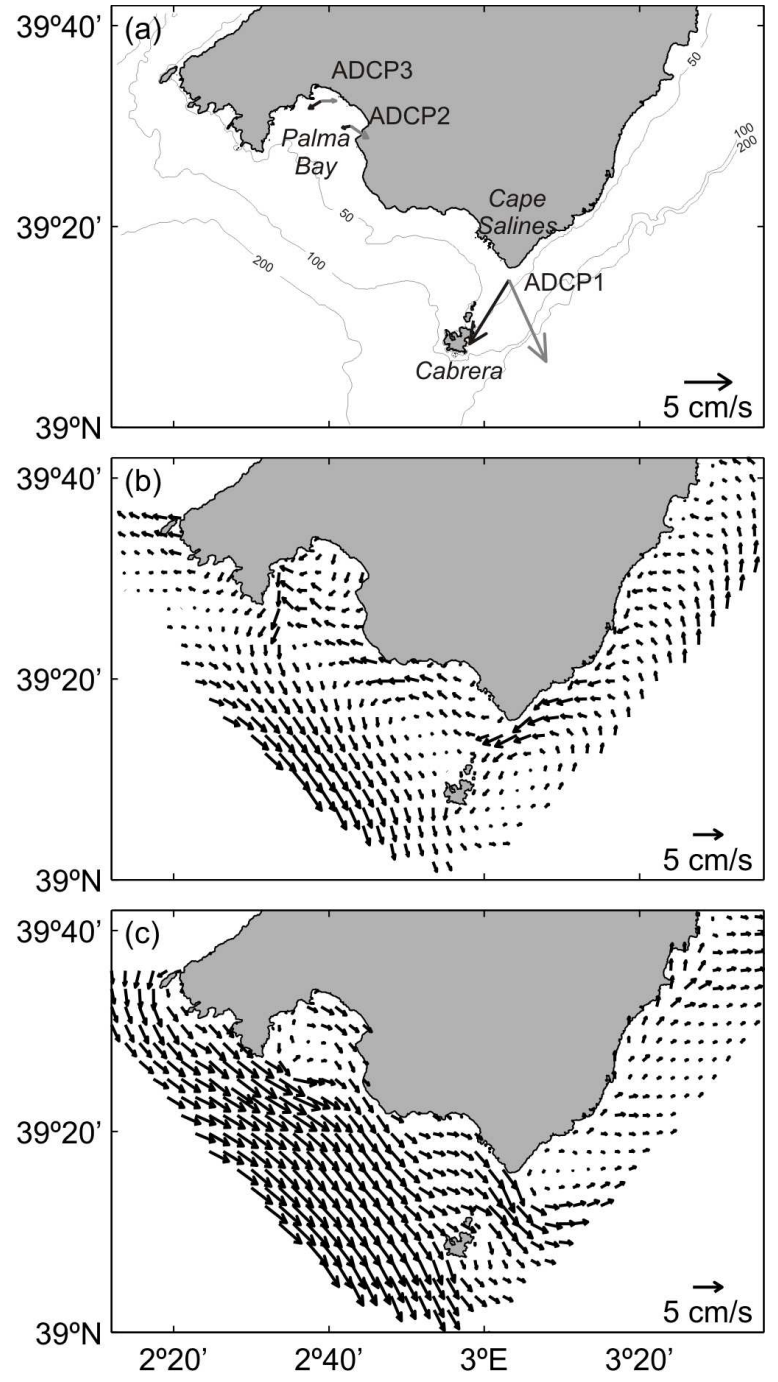

Figure 4

Figure 4 (a) Mean mode 1 (black) and mode 2 (gray) currents as obtained from ADCP records and (b) mean model-generated surface currents for mode 1 and (c) mode 2 winds. Note that the vector scale in panel (a) has been enlarged for clarity. 

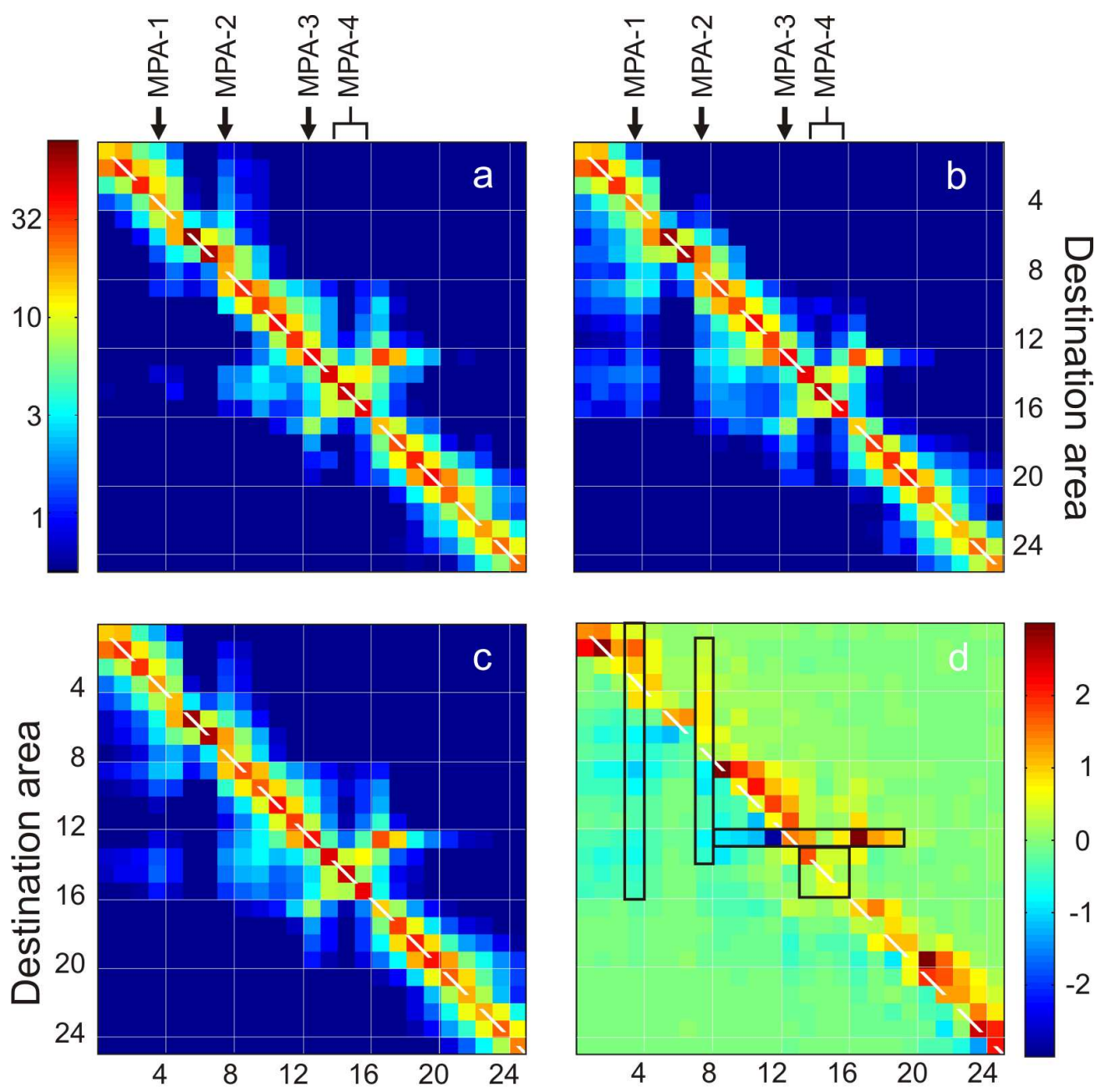

Source area

\section{Figure 5}

Figure 5. The connectivity matrix expressed as the \% of particles released from each of the zones on the $x$-axis arriving in zones on the $y$-axis. The color indicates the percentage of the larvae from a source location arriving at a destination location at the end of the larval development period ( 3 weeks). The dashed line represents self-recruitment. (a) The connectivity matrix for persistent

mode 1 episodes and (b) mode 2 winds. (c) The 10-year mean connectivity for the period considered and (c) seasonal differences (summer-spring). Note that the color bar for panels $a, b$ and $\mathrm{c}$ is logarithmic (upper left). Black boxes indicate the seasonal changes in the dispersal from/to the four MPAs shown in Fig. 1. $135 \times 163 \mathrm{~mm}(300 \times 300 \mathrm{DPI})$ 


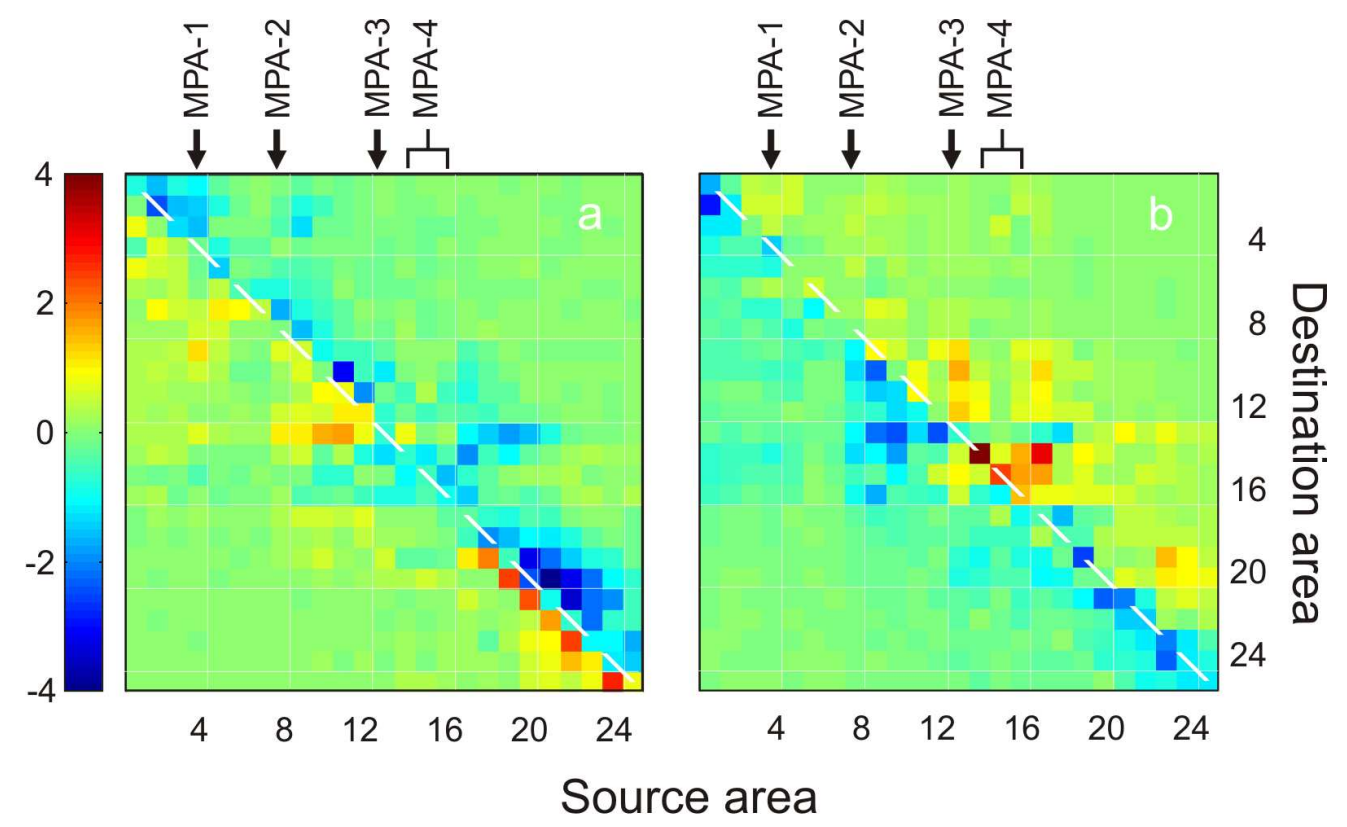

Figure 6

Figure 6. Variation in the connectivity matrix between years with different wind mode percentages. (a) Spring variations between 2008 and 2003 and (b) summer differences for 2005 through 2001. $135 \times 112 \mathrm{~mm}(300 \times 300 \mathrm{DPI})$ 


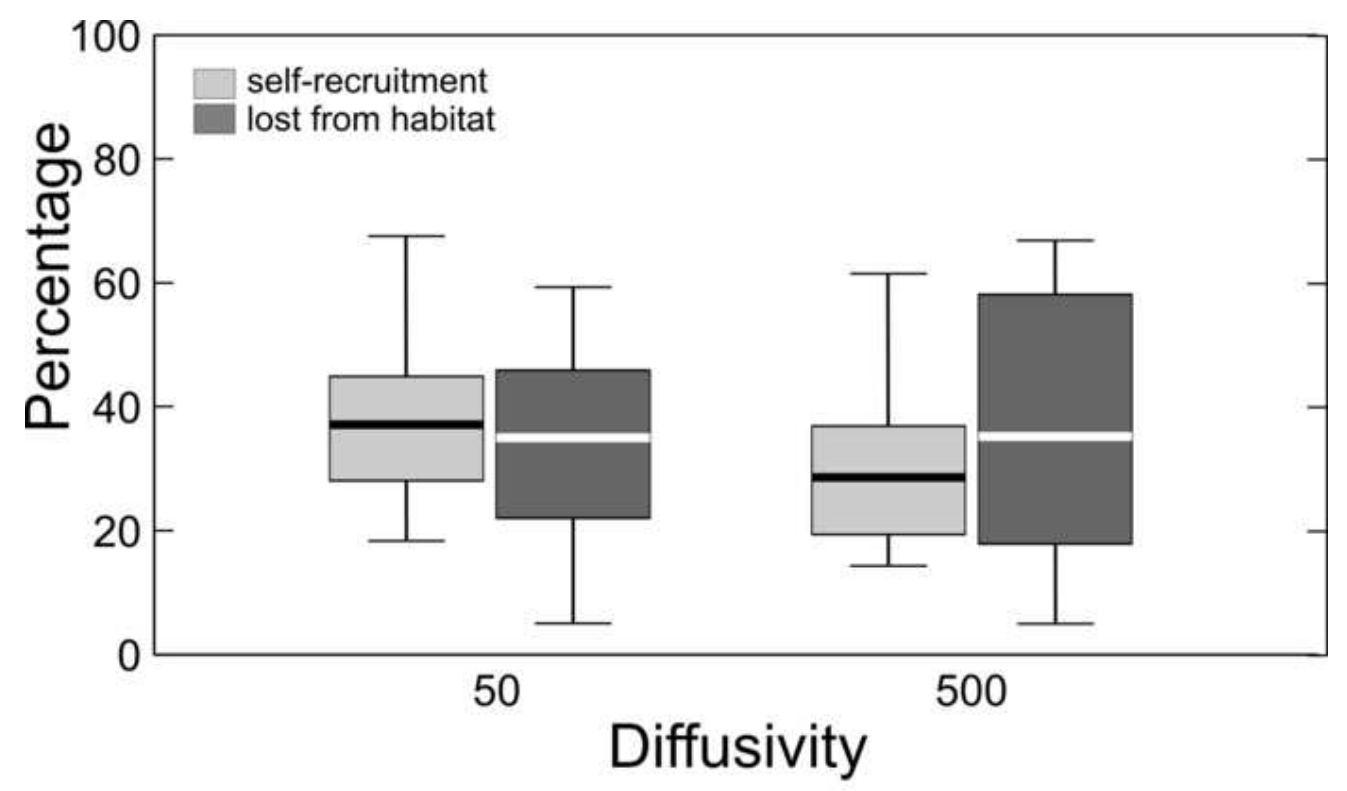

Figure 7

$58 \times 48 \mathrm{~mm}(300 \times 300$ DPI $)$ 

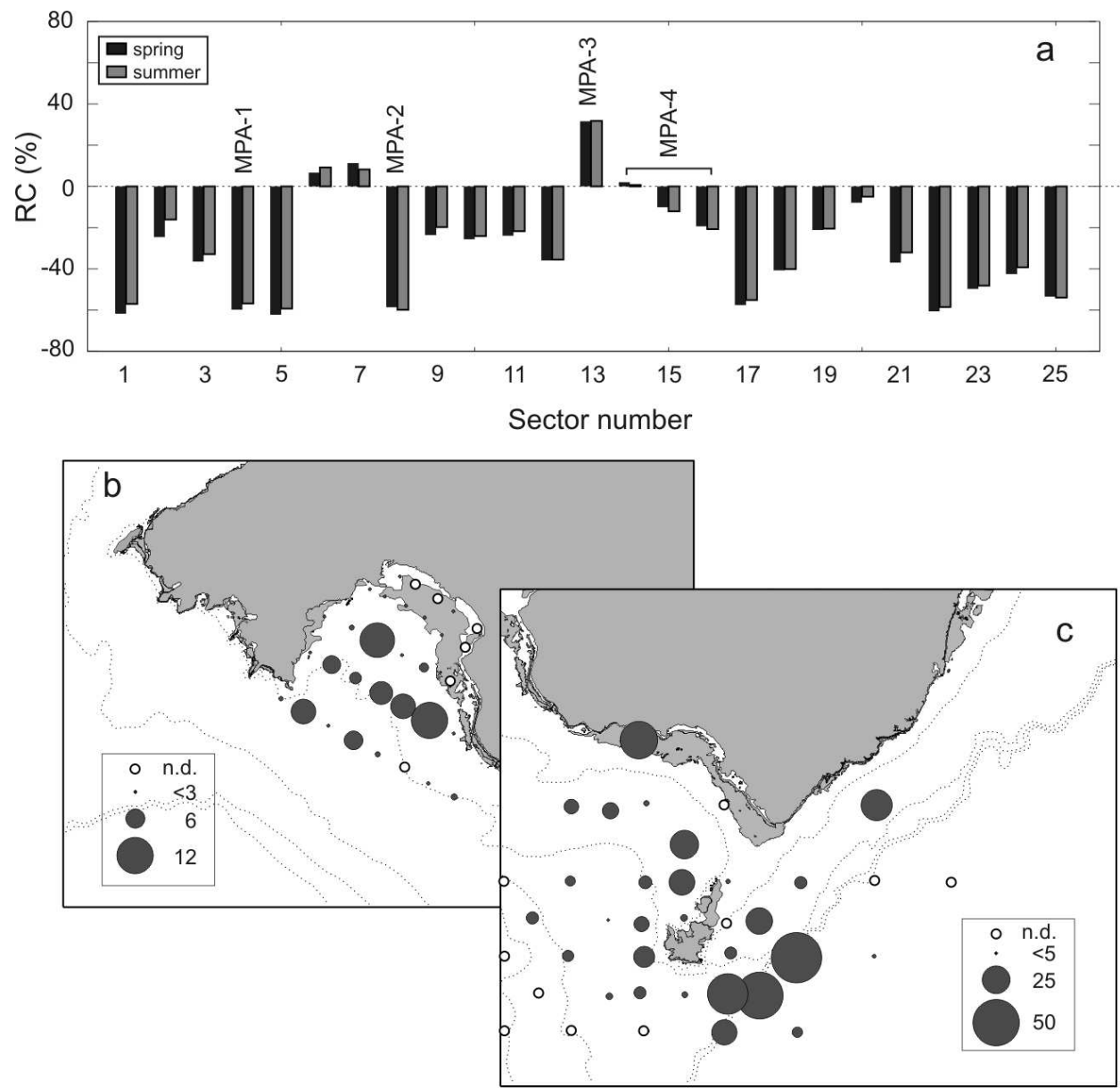

Figure 8

Figure 8. (a) RC (\%) for spring and summer in the different sectors of the study region. The sign indicates either negative or positive balance between export and recruitment. (b) The distribution of large-sized larvae of Chromis chromis in Palma Bay and around Cabrera (c) in surveys conducted in July 2010 and 2007, respectively. Units are ind. $10 \mathrm{~m}-2$. 